\title{
O ABUSO DE DIREITO NAS RELAÇÕES DE VIZINHANÇA
}

\author{
THE ABUSE OF RIGHTS IN NEIBOURING RELATIONSHIPS \\ Luiz Gonzaga Silva Adolfo, Andresa Guzati de Pellegrin, Aline da Luz Gattino e Maria \\ Helena Soares*
}

\begin{abstract}
Sumario: Introdução; $1 \mathrm{O}$ direito de vizinhança e limitações da propriedade; 2 As regras que devem nortear as relações de vizinhança; 2.1 Árvores limítrofes; 2.2 Passagem forçada; 2.3 Da passagem de cabos e tubulações; 2.4 Das águas; 2.5 Limites entre prédios e direito de tapagem; 2.6 Direito de construir; $3 \mathrm{O}$ abuso de direito nas relações de vizinhança e os meio de coibi-lo; $3.1 \mathrm{O}$ abuso de direito; 3.1.1 Das diversas teorias sobre o abuso do direito; 3.1.2 O abuso do direito e o ato ilícito; 3.1.3 O abuso de direito no Direito de Vizinhança; 3.2 Os meios para coibir o abuso de direito no Direito de Vizinhança; Considerações finais; Referências.
\end{abstract}

Resumo: Busca o presente artigo analisar o abuso de direito no Direito de Vizinhança, demonstrando os deveres e as obrigações para uma convivência social e pacífica, desde a preservação dos direitos de propriedade, perpassando as questões sociais e os interesses individuais, tudo na ótica do Direito Civil constitucionalizado.

Palavras-chave: Constitucionalização do Direito Civil. Direito das Coisas. Direito de Vizinhança. Abuso de direito.

Abstract: This article analyzes the abuse of rights in the Neighborhood Law, describing the duties and obligations for a peaceful social coexistence, since the preservation of property rights, passing by social questions and individual interests as well, in the view of the Constitutional Civil Law.

Key words: Constitutionalization of Civil Law. Law of Affairs. Neighborhood Law. Abuse of rights.

\section{INTRODUÇÃO}

O presente estudo visa a analisar o Direito de Vizinhança, instituto próprio do direito real que disciplina as relações entre os vizinhos, na perspectiva da satisfação de todos os que habitam este contexto, salientando que as regras que se apresentam destinam-se a regular a vida em sociedade diante dos possíveis conflitos em decorrência da proximidade ou da interferência dos prédios.

A regulação deste direito perpassa, também, a visão da função social da propriedade e os meios de coibir o abuso de direito, de modo que tais temas devam ser amplamente dissecados na busca de uma convivência harmoniosa, tornando o Direito de Vizinhança, por excelência, um direito/dever de todos os vizinhos.

Assim, o Direito de Vizinhança é visto no âmbito coletivo e na busca da harmonização da vida em sociedade.

\section{O DIREITO DE VIZINHANÇA E LIMITAÇÕES DA PROPRIEDADE}

O Direito de Vizinhança está amplamente relacionado às normas que regulam o direito à posse e à propriedade, perpassando as nuances das relações de convivência - enquanto direito, deveres e obrigações - da função social da propriedade e da dignidade da pessoa humana, delimitando os atos permitidos e aqueles que devem ser evitados, pois constituem direitos e deveres recíprocos.

Salienta-se que qualquer atuação inferior ao patamar da função social será interpretada como abuso de direito. A propriedade só tem sentido se satisfizer as faculdades de usar, gozar,

\footnotetext{
* Luiz Gonzaga Silva Adolfo Advogado, Mestre e Doutor em Direito pela Unisinos; professor do PPG em Direito da Universidade de Santa Cruz do Sul - Unisc -; professor do Curso de Direito da Universidade Luterana do Brasil - Ulbra (Gravataí/RS); Andresa Guzati de Pellegrin Advogada, Bacharel em Direito pela Universidade Luterana do Brasil - Ulbra (Gravataí/RS), Aline da Luz Gattino Advogada, Bacharel em Direito pela Universidade Luterana do Brasil - Ulbra (Gravataí/RS) e Maria Helena Soares Advogada, Bacharel em Direito pela Universidade Luterana do Brasil - Ulbra (Gravataí/RS).
} 
dispor e reivindicar com destinação de satisfazer as necessidades do ser humano. Portanto, sua finalidade mediata, emanada dos preceitos da Constituição Federal, é a fundamental alimentação do princípio da função social, elencado no inciso XXIII do artigo 5.․․

A funcionalização da propriedade introduz o critério de valoração de sua própria titularidade, que passa a exigir atuações positivas dos responsáveis, a fim de se adequarem à tarefa que a sociedade espera deles. O objetivo imediato do legislador é a tutela dos interesses privados, mas desses nada restaria se não fosse o objetivo mediato da função social da propriedade, o qual deve estar intimamente lincado nas relações de vizinhança, como dizem Tepedino e Schreiber: ${ }^{1}$

\begin{abstract}
A propriedade vai ganhando, assim, um novo papel no sistema civil-constitucional brasileiro, o de servir de garantia de acesso e conservação daqueles bens necessários ao desenvolvimento de uma vida digna, seja no âmbito dos bens públicos (como os recursos naturais), seja no âmbito dos bens privados (como o imóvel residencial ou bens móveis de uso essencial). Com esse significado, sim, parece possível falar em uma garantia de propriedade privilegiada aos olhos do texto constitucional, porque inteiramente a serviço do seu objeto fundamental: o pleno desenvolvimento da pessoa humana.
\end{abstract}

As relações de vizinhança pautadas na função social da propriedade buscam, também, a harmonia entre vizinhos, a qual só é possível diante do alcance dos objetivos econômicos, concomitantemente com os fins sociais. Pode-se dizer que as regras que regem o Direito de Vizinhança têm natureza preventiva, pois, uma vez observadas pelos proprietários, certamente seriam diluídas as discórdias resultantes do convívio diário. Nesse sentido, Brandão e Godoy ${ }^{1}$ enfatizam: "A fim de que a vida em comunidade seja a mais harmônica possível, devem imperar nas relações entre vizinhos, especialmente, os princípios da solidariedade e da boa-fé, além do princípio da função social da propriedade, sempre presente".

Também em relação à propriedade, assim conclui Moraes: ${ }^{2}$

No cenário solidarista deixou ela de ser definida como um espaço externamente delimitado, no âmbito do qual o proprietário teria ampla liberdade para desenvolver suas atividades e para emanação de senhoria sobre o seu bem. A renovada compreensão do instituto atribui à determinação do seu conteúdo para o âmbito da concreta relação jurídica, observados os centros de interesse extraproprietários e a existência de exercício conforme a função social, que se encontra definida pelo contexto constitucional.

Para entender a posse e a propriedade coadunada com o Direito de Vizinhança, faz-se mister analisar o Capítulo V do Código Civil, que trata dos direitos de vizinhança, numa ordem axiológica pautada pela relevância dos princípios da solidariedade e da igualdade, além da função social.

Nesse sentido, Farias e Rosenvald ${ }^{3}$ definem:

Nos direitos de vizinhança a norma jurídica limita a extensão das faculdades de usar e gozar por parte dos proprietários e possuidores de prédios vizinhos, impondo-lhes um sacrifício que precisa ser suportado para que a convivência social seja possível e para que a propriedade de cada um seja respeitada. Cada proprietário compensa seu sacrifício com a vantagem que lhe advém do correspondente sacrifício do vizinho.

Pode-se dizer que o Direito de Vizinhança traça regras relativas às propriedades imóveis contíguas, que buscam a composição de interesses entre o exercício de poderes 
proprietários e a preservação do conteúdo da propriedade vizinha. Deste conceito, ratificam-se os aspectos em relação à função social que a propriedade adquiriu a partir da promulgação da Carta Magna de 1988 e da vedação do abuso de direito. Portanto, a propriedade descrita no Código Civil não é mais aquela cujo titular tinha poder pleno, absoluto, individualista, com fins econômicos; hoje ela se apresenta com um novo enfoque, conforme descrevem Adolfo e Oliveira: ${ }^{4}$

Com o desfazimento da moldura individualista, a concepção de propriedade vem apanhando feição normativa com ares coletivos nos mais diversos ordenamentos jurídicos do globo, sendo expressamente recepcionada pela Constituição de 1988, no artigo 5.․, que trata das garantias e direitos individuais, em seu inciso XXIII, afirmação positiva de que "a propriedade atenderá sua função social".

Percebe-se que a propriedade deixou de ser um direito egoisticamente privado, um bem individual, onde os proprietários pudessem invocar reciprocamente seu direito absoluto, para se configurar numa visão complexa onde estão presentes direitos, deveres e obrigações na busca do bem comum e da coletividade, numa visão abrangente, aberta, genérica de proteção à propriedade, sendo o Direito de Vizinhança - capítulo do Direito das Coisas, no Código Civil - também tutelado com este enfoque.

Nesse contexto, as relações devem ser pautadas pela harmonia e equilíbrio, pois as restrições que venham a surgir afetarão, reciprocamente, todos os vizinhos. Os direitos de vizinhança, numa visão civil constitucionalista, são previsões legais que têm por objetivo regulamentar a relação social e jurídica que existe entre os titulares de direito real sobre imóveis, levando em consideração a proximidade geográfica entre os prédios e/ou apartamentos e buscando a coexistência pacífica entre vizinhos.

Nesta visão civil e constitucionalista, veja-se o que diz Aronne: ${ }^{5}$

O repensar inerente ao fenômeno da constitucionalização do Direito Civil introduziu novas reflexões acerca dos direitos reais, cuja gama de interesses centrais da disciplina deixava de estar ubicada tão-somente na figura do proprietário ou demais titulares, percebendo interesses distintos e até difusos em seu seio. O que se pode perceber como inovação não se dá quanto ao objeto de abrangência, mas ao interesse nas regulações.

Constata-se que as relações de vizinhança traduzem uma série de interesses e perspectivas que podem ir além daquelas ajustadas pela regra, mas, na perspectiva da dignidade da pessoa humana, todas as necessidades básicas dos cidadãos devem ter guarida na norma constitucional e em uma incessante busca por parte de todos os (cor)responsáveis, para sua efetivação.

Por outro lado, os vizinhos devem manter respeito mútuo, observando as regras de convivência, exercendo seus direitos e deveres de maneira tranquila e, com isso, pautando suas ações no sentido de não ofender a segurança, o sossego e a saúde de todos os que convivem no espaço considerado como de vizinhança, na expectativa do uso saudável da propriedade para que não haja necessidade de lançar mão dos meios coibitórios próprios devido ao mau uso. Neste diapasão, "O uso normal da propriedade é aquele que busca preservar a segurança, o sossego e a saúde dos moradores da região onde se situa o imóvel". 6

O artigo 1.277 do Código Civil diz do direito que o proprietário ou o possuidor tem para coibir o mau uso da propriedade, no tocante aos vizinhos, em relação à segurança, ao sossego e à saúde. Percebe-se que há uma ênfase considerável em relação aos aspectos negativos do uso do imóvel, quando, na verdade, o ideal seria que a paz reinasse nas relações de vizinhança, não sendo necessária, nem mesmo, a utilização dos meios permitidos para coibir tais abusos, pois a regra é a normalidade do uso da propriedade. 
O doutrinador Rizardo ${ }^{7}$ faz a seguinte interpretação do citado artigo: "[...] há uma extensão maior ao conteúdo negativo do uso do imóvel, abrangendo qualquer interferência negativa, isto é, emanação, decorrência, ou resultado que prejudique, mesmo que não decorra do uso".

A transgressão às regras da norma, retroelencada, caracteriza o abuso de direito e gera conflitos sociais.

A condição de vizinho está presente na sociedade, e basta habitar próximo a alguém para ser considerado como tal. A possibilidade de sofrer interferências oriundas de atos praticados em outros prédios é suficiente para delimitar o território do conflito de vizinhança, num sentido amplo, pois o ato praticado como interferente prejudicial vai até o limite de seu alcance em sua repercussão.

No ordenamento jurídico brasileiro, existem três tipos de restrições aos direitos de propriedade: as constitucionais, as administrativas e aquelas fundadas no Direito de Vizinhança, objeto específico do presente estudo.

As limitações inerentes aos direitos de vizinhança, positivadas no Código Civil, têm natureza propter rem, ou seja, vinculam-se ao prédio, assumindo-as quem quer que esteja em sua posse. A restrição/limitação acompanha o imóvel mesmo que haja mutação em sua posse. Elas são sempre recíprocas, afetando todos os vizinhos, concreta ou abstratamente, dependendo do grau de interveniência. "O conteúdo das limitações decorrentes da vizinhança está a meio caminho entre as obrigações e o direito real. A obrigação propter rem liga-se umbicalmente ao direito de propriedade". 8

A propriedade de um passa a ter relação diretamente com a de outro, quando há necessidade de uma interligação, ampliando as faculdades dos proprietários e possuidores na busca da efetivação da função social da propriedade. A intenção do legislador, ao prescrever na lei as limitações, teve, exatamente, o fito de regular aquelas ditas prejudiciais aos vizinhos no sentido de comunidade, não interessando ao Direito limitar todas as atividades a partir de um determinado prédio.

Na lição de Penteado, ${ }^{9}$ “"[...] acabam por imprimir uma diretriz ao modo de atuação do direito de propriedade nas relações entre vizinhos".

Salienta-se que o critério basilar quanto ao uso da propriedade é o normal, dentro dos parâmetros aceitáveis socialmente. No entanto, quanto ao Direito de Vizinhança, o Código Civil estabeleceu sua regulação concreta nos artigos 1.277 a 1.313. Assim, a seguir serão analisadas as regras que regem as relações de vizinhança.

\section{AS REGRAS QUE DEVEM NORTEAR AS RELAÇÕES DE VIZINHANÇA}

Conforme já referido e agora reiterando, as regras que constituem os direitos de vizinhança são recíprocas e destinam-se a evitar e a compor eventuais conflitos de interesses entre proprietários de prédios contíguos.

Nas relações de vizinhança, os interesses, os conflitos e a violação dos deveres jurídicos, entre outros, devem ser tratados na busca do direito de convivência, observando-se as regras e buscando-se a paz social. Para o alcance deste objetivo, os indivíduos devem pautar suas ações com base no equilíbrio e na boa convivência, evitando atos abusivos que são identificados a partir de determinados princípios violados, tais como a boa-fé, os bons costumes e a finalidade econômica e social da propriedade.

Ações que infringem os interesses individuais e da coletividade devem ser coibidas com os meios próprios, evitando-se o abuso de direito nas relações de vizinhança, buscandose o consenso e a harmonia no trato das causas em relação ao direito real e obrigacional.

As regras que devem nortear as relações de vizinhança estão elencadas no artigo 1.277 e seguintes do Código Civil e serão analisadas, sinteticamente, a seguir. 


\section{1 ÁRVORES LIMÍTROFES}

Esta regra se aplica às árvores próximas ou que estejam localizadas no meio de dois terrenos. A existência de árvores limítrofes pode suscitar diversos conflitos que, com base na doutrina de Farias e Rosenvald, ${ }^{10}$ podem ser analisados sob três prismas:

a) Quando a árvore tiver seu tronco na linha divisória, há presunção juris tantum de pertencer esta, em partes iguais, aos dois vizinhos, em condomínio necessário. Para ser a árvore comum, os frutos e o tronco são de copropriedade dos confiantes, da mesma forma que os demais proventos, bem como os encargos serão entre eles divididos, sendo que nenhum deles poderá cortá-la sem a anuência do outro.

b) Quando os frutos caírem naturalmente no terreno vizinho, em local próximo à linha divisória, pertencerão ao dono do local da queda com o intuito de evitar invasões em terreno alheio e eventuais discussões entre vizinhos. Cabe salientar, ainda, que esta regra diz respeito apenas aos frutos caídos naturalmente, não incidindo a norma naqueles vizinhos que utilizam outros mecanismos para alcançar tal objetivo. Contudo, se os frutos caírem em solo público pertencerão ao dono da árvore, e incorrerá em crime de furto quem porventura os colher.

c) Quando os ramos e as raízes ultrapassarem a divisão dos prédios, o dono do terreno invadido poderá cortá-los até o plano vertical divisório, independentemente de aviso prévio ou de qualquer outra formalidade, ou seja, a autoexecutoriedade de obrigação de fazer, resguardado, apenas, a ponderação do interesse social. A autorização para o corte independe de constatação de prejuízo ao vizinho, tendo em vista que é dever jurídico do proprietário agir da forma a manter as árvores em situação que não gere interferência na propriedade alheia. Porém, em alguns casos, o interesse social predomina sobre o interesse do proprietário, podendo, diante disso, haver necessidade de permissão para determinados cortes que somente serão autorizados mediante prejuízo ou risco iminente. ${ }^{11}$

\subsection{PASSAGEM FORÇADA}

A passagem forçada vem estabelecida no artigo 1.285 do Código Civil. Trata-se de um benefício reconhecido ao titular de prédio encravado, urbano ou rural, com o fito de sacramentar a solidariedade e a função social conjugada à necessidade econômica de exploração de imóvel encastoado com vistas à produtividade e ao bem da coletividade. Evidencia-se o verdadeiro direito potestativo constitutivo. $O$ encravamento poderá ser natural, ou seja, derivado de conduta imputável ao proprietário, ou aquele em que o proprietário se colocou em situação de encravamento por ter alienado a parte do imóvel que dava saída para a rua. Em ambos os casos, será assegurado o acesso à via pública, tanto para o proprietário como para o pretenso comprador. Esse tipo de passagem não será caracterizado pela gratuidade, pois se trata de direito de vizinhança oneroso e, na falta de acordo, para o caso em tela, a passagem forçada será fixada judicialmente. ${ }^{12}$

Salienta-se que a passagem forçada é direito de vizinhança e difere da servidão de passagem de trânsito. Esta tem fonte mediata na lei e no interesse social de sua exploração econômica, verdadeira obrigação propter rem, enquanto aquela é direito real de fruição oriundo da vontade das partes.

\subsection{DA PASSAGEM DE CABOS E TUBULAÇÕES}

O instituto da servidão administrativa normatiza a passagem de cabos, condutos e tubulações no subterrâneo de propriedade privada. O proprietário é obrigado a admitir a 
passagem através de seu imóvel por se tratar de serviços públicos essenciais, tais como água, luz, telefonia e gás. Novamente, prepondera o interesse social dos vizinhos; no entanto, a utilidade pública só se estabelecerá quando de outro modo não for possível, ou excessivamente onerosa, e não se estenderá ao espaço aéreo ou à superfície. Para o caso específico, caberá indenização em prol do proprietário, diante das restrições sofridas, assim como por eventual desvalorização, devendo as instalações serem realizadas da forma menos onerosa possível e observando-se as normas técnicas e de segurança. ${ }^{13}$

\subsection{DAS ÁGUAS}

O Código Civil disciplina este tópico nos artigos 1.288 a 1.296, dispondo a questão das águas apenas no que concerne ao Direito de Vizinhança, sendo as demais relações regulamentadas pelo Código das Águas. Sua disciplina relaciona-se ao proprietário ou possuidor de prédio mediata ou imediatamente inferior, que é obrigado a receber e escoar as águas pluviais, nascentes ou correntes que naturalmente escorram do prédio superior sem qualquer ônus, não lhe sendo permitido qualquer ato que impeça tal fluxo, sob pena de arcar com as consequências estabelecidas na legislação, pois ambos fazem jus a esse bem. ${ }^{14}$

É importante salientar que tanto o morador do prédio inferior quanto o do superior devem tomar as cautelas necessárias a fim de evitar danos que venham a obstruir ou danificar a utilização da água, tais como agressão ao meio ambiente, má utilização agrícola ou industrial e canalizações indevidas, entre outros, pois a intenção do legislador é preservar o interesse mútuo e a utilização correta da água.

\subsection{LIMITES ENTRE PRÉDIOS E DIREITO DE TAPAGEM}

A necessidade da demarcação surge juntamente com a propriedade, pois os marcos e as cercas preservam os interesses privados e ratificam a paz social diante de inúmeras lides que se travam nas relações de vizinhança. Todo proprietário possui o direito de tapagem, da forma que lhe convier, observando as disposições administrativas pertinentes, podendo haver a divisão proporcional de custos entre os proprietários, desde que de comum acordo, salvo exceções em situações especiais, tais como cercas para proteção de pequenos animais. A delimitação da propriedade deve seguir o já determinado e demarcado administrativamente, ou vir a ser feita por ação judicial própria. ${ }^{15}$

\subsection{DIREITO DE CONSTRUIR}

Este tópico deve ser analisado à luz da função social da propriedade e do direito especial de construir regulado pelo Código Civil.

A função social da propriedade já foi objeto de análise ao longo deste estudo; no entanto, no arcabouço do Direito de Vizinhança, alcança a concepção traçada pelos direitos de segunda dimensão, em relação à habitação e à moradia digna, como um dos parâmetros da dignidade da pessoa humana. Neste diapasão, o imóvel deve atender à função social sem, no entanto, que isso implique ofensa a regras de natureza administrativa ou aos direitos de vizinhança.

O direito de construir, à luz da função social, sedimenta a vinculação dos direitos de vizinhança com a função social da propriedade, pois eles se coadunam e não podem ser vistos num enfoque estanque. Se assim fosse, não se prestariam a atingir os interesses da coletividade frente ao interesse particular.

O direito de construir não pode, então, ser entendido apenas como uma faculdade do proprietário, limitado aos direitos de vizinhança e pelos regulamentos administrativos; deve 
ser visto e interpretado numa visão civil constitucionalista que dimensiona o princípio da função social da propriedade à categoria de direito fundamental garantido pela Carta Magna. Desse modo, há a necessidade de políticas públicas de desenvolvimento que efetivem tal preceito, dimensionando quando, como e o que construir e observando os ordenamentos urbanísticos próprios de cada região. ${ }^{16}$

Porém, quando o direito de construir for regulado eminentemente pelo Código Civil, busca o equilíbrio das partes, em caso de conflito, possibilitando-lhes que exerçam seus direitos de fruição e edificação, evitando frustrações de vizinhos e da coletividade.

$\mathrm{O}$ direito de construir deve se pautar no respeito à pessoa humana, evitando ações que prejudiquem a saúde, o sossego e a segurança de vizinhos.

No que pertine às limitações de construção, no Direito de Vizinhança, encontram-se regulações diversas que visam a proteger a vida privada da entidade familiar da perturbação dos vizinhos em relação à abertura de janelas, dimensões de espaços, normas para a construção de paredes divisórias e muros e orientações para construção e reformas em geral, entre outras. Salienta-se que aquele que não observar as normas próprias e provocar danos a terceiros por ocasião da construção de obra nova ou reforma responderá objetivamente. ${ }^{17}$

Cabe ainda referenciar que, além das normas estabelecidas no Código Civil em relação à construção, no capítulo que trata dos direitos de vizinhança, cabe ao Município autorizar, fiscalizar e reprimir as construções urbanas frente ao Código de Posturas e ao Plano Diretor.

Ante o exposto, pode-se afirmar que os direitos de vizinhança são limitações impostas por normas jurídicas a propriedades individuais com o intento de conciliar interesses de proprietários vizinhos, de modo a regular a convivência social. Na mesma esteira, as regras de vizinhança têm por objetivo harmonizar a vida em sociedade e o bem-estar, sem deixar à margem as finalidades do direito de propriedade. ${ }^{18}$

Normalmente, as limitações são impostas com obrigação de permitir a prática de certos atos pelos vizinhos e de se abster da prática de outros com o fito de assegurar a convivência amistosa. Em relação ao primeiro caso, que implica uma sujeição, podem ser mencionadas as seguintes situações: a que incide sobre o vizinho do prédio encravado, obrigado a conceder passagem a seu dono; a que recai sobre o dono do prédio inferior, obrigado a receber as águas que fluem naturalmente do superior; a que impõe ao proprietário a obrigação de permitir a entrada do vizinho, etc.

Dentre as regras que determinam uma abstenção, aponta-se a proibição imposta ao proprietário de fazer mau uso de seu prédio, suscetível de prejudicar a saúde, o sossego ou a segurança do vizinho.

\section{O ABUSO DE DIREITO NAS RELAÇÕES DE VIZINHANÇA E OS MEIOS DE COIBI-LO}

O abuso de direito é objeto de atenção na atualidade, mormente pela dificuldade de conceituá-lo e pela abundância de teorias que surgiram a seu respeito. A isso se inclui a importância e a relevância do tema, uma vez que a utilização abusiva do direito é, frequentemente, encontrada na realidade fenomênica, apresentando problemas desde sua identificação até as mais diversas formas de danos a suas vítimas e, por consequência, levando à necessidade de coibi-lo.

Sabe-se que os direitos de vizinhança são previsões legais que têm por intento regulamentar a relação social que existe entre os titulares de direitos reais sobre imóveis, levando em consideração sua proximidade geográfica, porquanto criados por lei, diante da necessidade da coexistência pacifica entre vizinhos.

Como se exporá adiante, o abuso de direito tem se revelado nas relações entre vizinhos, mostrando-se indispensável a análise de tal instituto jurídico, a fim de se estabelecer 
certo entendimento acerca de sua definição e finalidade, bem como verificar suas teorias e ligação com o ato ilícito para, então, delinear sua incidência no direito de vizinhança, instituindo, por fim, um meio de restrição.

\subsection{O ABUSO DE DIREITO}

Fixar um conceito jurídico é sempre uma tarefa complexa, contudo é possível estabelecer que o abuso de direito como o exercício de um direito subjetivo vai além dos limites a que foi proposto pela ordem jurídica ou, ainda, nas palavras de Porcherot: ${ }^{19}$ "Abusase do seu direito quando, permanecendo nos seus limites, se visa um fim diferente daquele que para ele teve em vista o legislador".

Diante deste conceito, pode parecer que o abuso de direito se refere, exclusivamente, aos direitos subjetivos; porém a teoria pode e deve ser aplicada a outras prerrogativas em virtude da estreita ligação entre o abuso de direito e o princípio da boa-fé, possibilitando uma expansão do instituto. Segundo Pedro Modenesi, "Assim, garante-se a aplicação da teoria do abuso a situações que não se enquadram nos moldes próprios do direito subjetivo, como poderes, faculdades, liberdades e outras posições jurídicas.

Embora exista esta expansão do instituto, é cediço aduzir que sua ligação com o direito subjetivo é estreita, tornando imprescindível a noção do tema. Para Alberto Trabuchi, ${ }^{21}$ a compreensão do tema está na liberalidade do sujeito para o exercício, ou não, de um direito garantido pelo ordenamento jurídico; seu objetivo precípuo é o de satisfazer interesse próprio. E, para que essa expressão de liberdade ocorra, faz-se necessária a conjuntura de dois elementos constitutivos, quais sejam interesse e vontade.

A doutrina de Cunha de $\mathrm{Sá}^{22}$ esclarece que, diante de um direito subjetivo, seu titular poderá comportar-se sob a forma de três distintas hipóteses, com as quais vem a apresentar três diversas classificações para sua conduta. Como primeira hipótese, surge o comportamento do indivíduo em conformidade com a estrutura formal do direito subjetivo exercido e com o valor normativo que lhe é inerente. Nesta conjuntura, apresenta-se o comportamento classificado em exercício regular e legítimo de um direito. $\mathrm{Na}$ segunda hipótese, o comportamento do titular do direito subjetivo é diferente ou contrário à estrutura formal de tal direito, não se acomodando com a forma estabelecida legalmente. Essa hipótese configura um ato ilícito. Como última hipótese, apresenta-se o comportamento do sujeito em conformidade com a estrutura formal do direito subjetivo, porém em desconformidade com o valor apresentado como fundamento jurídico de tal direito. A isso se chama abuso de direito.

A finalidade primordial do abuso de direito é a ordenação da vida em sociedade, eliminando as condutas lesivas que contrariam o fim social e o bem comum conforme sua determinação pelo ordenamento jurídico como ideal de justiça.

\subsubsection{Das diversas teorias sobre o abuso do direito}

Ao longo do tempo, várias teorias buscaram assegurar o equilíbrio entre as relações sociais mediante a definição de um critério para a identificação do exercício desconforme de um direito em relação ao espírito da lei que o instituiu. A análise das teorias será feita apenas com o objetivo de melhor compreensão do tema; portanto, ela será limitada à identificação de somente três, quais sejam: a teoria subjetiva, a teoria objetiva e a teoria mista.

As teorias subjetivas advêm da doutrina da emulação, ${ }^{23}$ que foi desenvolvida no Direito Medieval e tem suas raízes no próprio Direito Romano. Por essa concepção, o abuso de direito começou a ser aceito em circunstâncias em que ficasse clara, na atitude do agente, a intenção de prejudicar alguém. Os indivíduos dispõem de liberdade para exercer seu direito, desde que não o façam na exclusiva intenção de prejudicar outrem. Para essa teoria, são três 
os elementos caracterizadores do abuso do direito: exercício de um direito, intenção de causar dano e inexistência de interesse econômico.

Percebe-se, portanto, que é na análise do animus que se identifica a ocorrência, ou não, do abuso no exercício do direito. Se, no momento da conduta, não esteve presente a intenção de prejudicar terceiros, essa não caracterizará abuso, e, sim, exercício regular do direito. A gravidade do dano ou qualquer outro aspecto objetivo não será considerado para a aferição do abuso.

Essa teoria não prosperou, haja vista ser insuficiente para reprimir o exercício abusivo do direito e também por empregar a doutrina da aemulatio, inconcebível em tempos modernos, por ter como base a propriedade e o medo de o proprietário vir a perdê-la, o que se mostra incompatível com a Constituição Federal, a qual vem estabelecer a função social da propriedade. ${ }^{24}$

De outro modo, a teoria objetiva, também conhecida como teoria finalista, entende como abuso o exercício anormal de um direito quando ele deixa de atender à finalidade que justifica sua criação. $\mathrm{O}$ ato abusivo, portanto, é um ato anormal, porque contraria a finalidade econômica e social do direito.

Não se indaga da intenção do agente; indaga-se, pura e simplesmente, do ato, de seu conteúdo, da existência de desvantagem econômica e se é ou não reprovado socialmente.

Observa-se que, mesmo refutando a intenção do agente, a teoria finalista está intimamente ligada à teoria subjetiva, pois, exercendo seu direito com intenção de prejudicar outrem, como pressupõe a teoria subjetiva, também estará ferindo os fins propostos pela teoria finalista. ${ }^{25}$

Em suma, a teoria finalista pode ser entendida como a reprovação dos atos que contrariam os fins sociais e o bem comum, mesmo estando sobre a égide da lei.

Posteriormente, surgiu a teoria mista com o objetivo de preencher as lacunas existentes nas teorias anteriormente estudadas, conjugando os critérios objetivos e subjetivos para a definição do abuso de direito. Por este critério, o abuso de direito, por algumas vezes, restaria configurado pela negligência do agente e, por outras, pela intenção de prejudicar terceiros.

Porém, de acordo com Boulos, ${ }^{26}$ quando a teoria objetiva é aplicada tecnicamente e em toda a sua plenitude, estará incorporando a teoria subjetiva, assim tornando irrelevante, na atualidade, a referência à teoria mista.

\subsubsection{O abuso do direito e o ato ilícito}

A leitura do artigo 187 do Código Civil pode levar ao entendimento de que o abuso de direito nada mais é do que uma ilicitude, até porque está (substituímos o embora) expressamente considerado ato abusivo como ato ilícito. Isso não quer significar que as condutas sejam idênticas: o abuso de direito é uma das formas pelas quais a ilicitude se manifesta. ${ }^{27}$

O fator primordial para a diferenciação entre o abuso de direito e ato ilícito é a natureza da violação a que eles se referem. Tem-se no ato ilícito uma afronta direta a um comando legal, enquanto no abuso de direito se tem o exercício anormal de um direito próprio. No ato ilícito a conduta não tem respaldo legal; já no abuso ela encontra suporte no ordenamento jurídico, mas viola os valores que legitimam o direito.

Embora existam sutis diferenças entre as duas práticas, é imperioso afirmar que tanto o ato ilícito como o abuso do direito se encontram no plano da antijuridicidade, podendo apresentarem, inclusive, as mesmas sanções. 
Em voto proferido em sede de recurso de apelação, a Desembargadora Liége Puricelle Pires explica que a regra contida no artigo 187 do Código Civil, que comporta o abuso de direito, surge da prática de um ato ilícito objetivo. E ainda, em suas próprias palavras, lê-se: ${ }^{28}$

A grande diferença entre os ilícitos é que o ilícito subjetivo é apriorístico, pois já se sabe, de antemão, quais são os ilícitos subjetivos, pois provindo da norma sua violação culposa ou dolosa, todo ilícito subjetivo é apriorístico, tendo resultado previamente definido. Já o ilícito objetivo não é apriorístico, mas casuístico, pois apenas no caso concreto é possível observar se o ato implicou em abuso, ou não, do exercício de um direito. Uma mesma conduta pode ensejar ato ilícito objetivo em um caso, e não caracterizar em outro, pois o ato ilícito objetivo é dotado de certa plasticidade.

Daí já se vê que o ato ilícito objetivo está desatrelado da culpa, mas atrelado ao comportamento do agente. E em se tratando de dano causado a terceiros pelo uso da propriedade imóvel, com reflexos em direitos de vizinhança, verifica-se outra peculiaridade, concernente à consequência jurídica do ato, a qual depende da natureza da utilização do imóvel e dos incômodos causados.

E isso porque as próprias relações de vizinhança trazem ínsitas a sua essência um limite de tolerância, uma margem de incômodo imposta a quem vive em sociedade, o que Cristiano Chaves de Farias e Nelson Rosenvald chamam de "encargos ordinários de vizinhança”.

Hodiernamente, existe uma proposição para a desconstrução do abuso de direito. Por este entendimento, o instituto não está contido no artigo 187 do Código Civil, mas no $§ 2 .^{.}$de seu artigo 1.228. Esta afirmativa advém da análise do surgimento do abuso de direito, pois este apareceu para combater a ilicitude dos atos de emulação, sendo seu precedente imediato.

Como expoente desta teoria, afirma Ascensão: ${ }^{29}$

O abuso do direito surgiu como resposta doutrinária aos atos emulativos, contra os quais não se encontrava previsão específica nos códigos civis. A estes se assimilaram os atos chicaneiros. Mas o art. 187 não fala nem em atos emulativos nem em atos chicaneiros. Recorre a categorias diferentes. Curiosamente, os atos emulativos surgem previstos noutro lugar do $\mathrm{CC} / 02$ : o art. $1.228 \S 2^{\circ}$, no domínio do Direito das Coisas.

É diante desse panorama que nos propomos proceder a uma desconstrução do abuso do direito. Apressamo-nos a esclarecer que não está aqui subjacente nenhum apelo a uma posição filosófica. Queremos apenas exprimir que nos propomos empreender uma análise crítica da categoria (que poderá ser até uma categoria aparente) para sondar seus pressupostos e sua solidez.

Nesta conjuntura, o jurista português afirma que o abuso de direito não se apresenta como conteúdo do artigo 187 do Código Civil, eis "que nem sequer usa a expressão 'abuso do direito". ${ }^{30}$ E prossegue: "Se quisermos continuar a recorrer à categoria doutrinária do abuso do direito, mais vale referi-la às situações de Direito da Vizinhança, contempladas no art. $1.228 \S 2$. . . Mas então falar de atos emulativos ou chicaneiros já diria tudo". ${ }^{31}$

Diverso é o entendimento de Boulos, ${ }^{32}$ para quem o artigo 187 dispensaria a tratativa que a propriedade recebe por via do $\S 2 .^{\circ}$ do artigo 1.228 , pois os limites impostos pelo princípio da boa-fé seriam suficientes para reprimir atos de emulação. Assim, afirma:

[...] a proibição dos atos emulativos (art. 1228, § $2^{\underline{o}}$ ), entendemos que eles se encontram proibidos já pelo artigo 187 que, ao considerar ato ilícito o exercício do direito em manifesto excesso aos limites impostos pela boa-fé, certamente reprova a prática de qualquer ato emulativo por quem quer que seja que esteja investindo em qualquer situação jurídica subjetiva. 
Em decorrência dos crescentes conflitos que envolvem o direito de vizinhança e o desgaste psicológico que acomete os envolvidos, a questão de maior relevância é manter um ambiente saudável entre vizinhos, independente da utilização do artigo 187 ou do $\S 2 .^{\circ}$ do artigo 1.228 para reprimir atos incompatíveis com o sossego, a tranquilidade e a segurança.

\subsubsection{O abuso de direito no Direito de Vizinhança}

Muito embora a Constituição Federal apresente proteção à propriedade privada, ela também lhe confere a necessidade de atender a sua função social, impondo uma limitação.

Entretanto, essa não é a única limitação imposta à propriedade, porquanto o $\S 2 . .^{\circ}$ do artigo 1.228 do Código Civil ${ }^{33}$ também estabelece limites, conforme se extrai de sua leitura: "São defesos os atos que não trazem ao proprietário qualquer comodidade, ou utilidade, e sejam animados pela intenção de prejudicar outrem".

Uma vez que o $\S 2 .^{\circ}$ do artigo 1.228 vem restringir a faculdade que o proprietário detém de usar e gozar da coisa, apresentando proibição a condutas que atentem a prejudicar terceiros e que não tragam comodidade ou utilidade ao proprietário, apresenta-se o abuso de direito na propriedade privada quando for utilizada de forma nociva, perturbando ou causando dano a outros proprietários.

No capitulo específico do Direito de Vizinhança também o direito de propriedade fica subordinado ao exercício saudável do direito, constituindo abuso se o ato prejudicar a segurança, o sossego e a saúde dos vizinhos. O uso anormal da propriedade está descrito no artigo 1.277 do Código Civil, apresentando um numerus clausus, ou seja, o trinômio saúde, segurança e sossego. Se o ato extrapolar os limites do trinômio também extrapolará o direito, surgindo conflitos de vizinhança. ${ }^{34}$

Prá $^{35}$ destaca que,

Em voto na Apelação Cível de n. ${ }^{\circ}$ 70041865668, o Desembargador Pedro Celso Dal

Efetivamente, a Lei Civil protege os vizinhos do uso de prédio que extrapole a normalidade. Assim, o ocupante de um prédio tem, a favor de si, o direito de impedir que o mau uso da propriedade vizinha venha a prejudicar a segurança, o sossego e a saúde dos que a habitam.

E a responsabilidade, nesses casos, independe de culpa, posição privilegiada, porém que não isenta a parte de fazer prova da efetiva ocorrência do mau uso da propriedade.

O trinômio apresenta conceitos jurídicos indeterminados como segurança, representando valores de solidez, estabilidade e incolumidade pessoal dos vizinhos; o sossego, apresentando valores como paz e tranquilidade; e, por fim, a saúde, apresentando funções biológicas e psicológicas, direitos inerentes a qualquer ser humano e em qualquer relação social. ${ }^{36}$

\subsection{OS MEIOS PARA COIBIR O ABUSO DO DIREITO NO DIREITO DE VIZINHANÇA}

O uso anormal da propriedade pode ocorrer na prática de atos ilegais, abusivos ou excessivos, muito embora esta distinção no Direito de Vizinhança não se apresente como necessária, porque até o uso normal da propriedade pode se apresentar como um mau uso, por exemplo, quando ocasionar intervenções em imóveis vizinhos. Nesse sentido, esclarecem Farias e Rosenvald: ${ }^{37}$ 
Assim, em termos práticos, é igualmente ofensiva a conduta de quem produz ruídos excessivos e de alguém que emite ruídos moderados, mas por falha na construção (isolamento acústico) culmina por infringir danos excessivos ao vizinho.

A teoria do abuso de direito é utilizada para recompor relações em que o uso indevido da propriedade causa prejuízos aos vizinhos. A solução para a composição dos conflitos apresenta-se em duas categorias de ações judiciais: se o prejuízo já ocorreu, a solução é a ação indenizatória; apresentando-se situação continuativa, a ação deve ser proposta nos termos do artigo 1.277. Será, portanto, ação de obrigação de fazer ou não fazer cominada com multa. "Pede-se a cessação dos fatos ou atos perturbadores e a indenização dos prejuízos já causados. A ação de nunciação de obra nova é admissível, enquanto em curso e não terminada a obra perturbadora". ${ }^{38}$

Gonçalves $^{39}$ apresenta uma síntese para a composição dos conflitos na vizinhança:

a) Se o incomodo é normal, tolerável, não deve ser reprimido, a reclamação da vitima será aferida segundo o critério do homo medius. Só serão atendidas questões relativas a danos considerados insuportáveis ao home normal;

b) se o dano for intolerável, deve o juiz, primeiramente, determinar que seja reduzido a proporções normais, fixando horários de funcionamento (somente durante o dia, p. ex.), exigindo a colocação de aparelhos de controle de poluição, levantando barreiras de proteção etc. [...];

c) se não for possível reduzir o incômodo a níveis suportáveis, por meio de medidas adequadas, então determinará o juiz a cessação da atividade, fechando a indústria ou o estabelecimento ou até demolindo a obra, se forem de interesse particular;

d) se, no entanto, a causadora do incômodo for indústria ou qualquer atividade de interesse social, não se determinará o seu fechamento ou a cessação da atividade. Se o incômodo não puder ser reduzido aos graus de tolerabilidade mediante medidas adequadas, será imposto ao causador do dano a obrigação de indenizar o vizinho (CC, art. 1278).

Portanto, os principais remédios jurídicos a serem utilizados pelos vizinhos que sofrem prejuízos por abuso do direito de propriedade apresentam-se como ações indenizatórias, ações cominatórias e ação de dano infecto.

A ação indenizatória é utilizada quando os atos prejudiciais já cessaram, pretendendose restabelecer a situação fática anterior ao cometimento do abuso, demonstrando o vizinho o que efetivamente perdeu e o que deixou de ganhar.

A ação cominatória é utilizada quando o ato nocivo ainda está em curso, para fazê-lo cessar, com imposição de multa diária (aistreinte). Nessa ação, o vizinho busca a tutela inibitória, característica das obrigações de fazer ou não fazer, com possibilidade de antecipação de tutela. ${ }^{40}$ Possui legitimidade para a propositura da ação cominatória o possuidor direto ou o indireto, pois independe da prova de propriedade, conforme o ensinamento do Desembargador Glênio José Wasserstein Hekman: ${ }^{41}$

Tem-se, segundo a inteligência do art. 1.277 DO Código Civil, que a propositura da ação cominatória não exige a prova da propriedade, basta ser compromissário comprador e/ou possuidor (direto ou indireto) para estar legitimado a fazer cessar a interferência produzida pelo prédio vizinho. Neste sentido, leciona CARLOS ROBERTO GONÇALVES, “o art. 1.277 do Código Civil estabeleceu um preceito genérico sobre o mau uso da propriedade, em termos claros e apropriados. As interferências ou atos prejudiciais à segurança podem ser classificados em três espécies: ilegais, abusivos e lesivos, [...] A ação apropriada para tutela dos direitos mencionados é a cominatória, na importará ao réu a obrigação de se abster da prática dos atos prejudiciais ao vizinho, ou a tomar medidas adequadas para redução do incômodo, sob pena de pagamento de multa diária, com base nos arts. $287,461, \S 4^{\circ}$ 
e 644 do Código de Processo Civil. Pode a ação ser ajuizada pelo proprietário, pelo compromissário comprador titular de direito real ou pelo possuidor". [...] Do exposto concluí-se, que não somente os proprietários padecem de prejuízo causado pelo vizinho (próximo ou confinante), mas também o possuidor direito ou indireto. Assinalo, o direito de vizinhança tem como escopo o mau uso da propriedade (coisa), pela mensuração de condutas seja de proprietários seja de possuidores que extrapolam o razoável e prejudicam a segurança, sossego e saúde de vizinhos (proprietários, usufrutuários, locatários, comodatários, etc.), titulares de direitos subjetivos, na condição de titulares de direito real e/ou obrigacionais, aptos a inibir o uso anormal da propriedade ou da posse.

No mesmo contexto, em voto proferido na Apelação Civil n. ${ }^{\circ}$ 70017338823, explica o Desembargador Glênio José Wasserstein Hekman, ${ }^{42}$ citando a doutrina de Fábio Ulhoa Coelho:

Sem dúvida, algumas das relações jurídicas associadas ao direito de vizinhança envolvem proprietários, possuidores e pessoas que habitualmente costumam encontrar-se, assim, exige-se tanto dos proprietários como dos possuidores de imóveis vizinhos conduta compatível com um viver harmonioso e saudável garantindo-se aos vizinhos um mínimo de sossego, tranquilidade e segurança.

$\mathrm{Na}$ doutrina de Fábio Ulhoa Coelho "os direitos de vizinhança tratam de matérias afetas às relações entre proprietários ou possuidores de imóveis vizinhos, fornecendo pautas para superação dos conflitos de interesses que entre eles venham a surgir. E como são frequentes, inúmeros, acentuados e psicologicamente desgastantes esses conflitos! Por mobilizarem emoções primitivas do homem - que se ameaçado em seu territóriose (sic.) não desfruta como gostaria do imóvel de seu domínio ou posse - e dizerem respeito a relações entre pessoas que costumam encontrar-se cotidianamente, em geral os conflitos associados aos direitos de vizinhança têm pouca ou nenhuma relevância econômica, mas atormentam intensamente os envolvidos".

Ainda se pode utilizar a ação de dano infecto, que será proposta quando houver potencialidade da ocorrência do dano futuro, e não se o dano já aconteceu. Ocorrendo dano intenso que afete toda uma comunidade, é possível o ajuizamento de ação civil pública.

\section{CONSIDERAÇÕES FINAIS}

As normas relativas ao Direito de Vizinhança vão além daquelas expressas no ordenamento jurídico, perpassando questões sociais e éticas, entre outras, e prescrevendo, portanto, comportamentos gerais e abstratos, tudo com o fito de evitar o desentendimento e o abuso de direito, pois o que se espera das relações de vizinhança são comportamentos socialmente adequados e nos parâmetros da boa-fé objetiva, lembrando sempre da função social, finalidade basilar da propriedade, que deve primar pelo interesse coletivo.

A sensação do domínio e do uso da propriedade precisa ser suportada por todos os vizinhos, sendo a má utilização caracterizada como abuso de direito. Assim, para que reine a paz social, os detentores das propriedades vizinhas deverão ter em mente que o direito de uso e gozo está, amplamente, vinculado a todos.

Portanto, o direito de vizinhança deve estar pautado num ambiente saudável, onde o coletivo deve preponderar ou estar no mesmo âmbito do direito individual, garantindo, assim, a propriedade-função.

\section{REFERÊNCIAS}


ADOLFO, Luiz Gonzaga Silva. Obras privadas, benefícios coletivos: a dimensão pública do Direito Autoral na sociedade da informação. Porto Alegre: Sergio Antonio Fabris, 2008.

; OLIVEIRA, Paula Cristina Koerig de. Pra não dizer que não falamos de espinhos: a constitucionalização do Direito Civil e a difícil concretização da ideia de repersonalização em ações de direitos reais nos Tribunais brasileiros. Revista do Direito UNISC, Santa Cruz do Sul, n. 32, pp. 53-77, jul./dez. 2009. 28 dez. 2009, p.10. Disponível em: <http://online.unisc.br/seer/index.php/direito/article/view/1187 /887>. Acesso em: $1 .{ }^{\circ}$ nov. 2010.

ARONNE, Ricardo. Propriedade intelectual e direitos reais: um primeiro retomar da obviedade. Revista do Direito da UNISC, Santa Cruz do Sul, n.28, pp. 211-249, jul./dez. 2007. Disponível em: <http://online.unisc.br/seer/index.php/direito/article/ viewfile/ 186/147>. Acesso em: 1.ำ nov. 2010.

ASCENSÃO, José de Oliveira. A desconstrução do abuso de direito. In: AGUIAR JR., Ruy Rosado de (Org.). Jornada de Direito, 3. Anais. Brasília: Conselho da Justiça Federal, 2005, p. 32. Disponível em: <http://daleth.cjf.jus.br/revista/ enunciados/IIIJornada.pdf>. Acesso em: 1. $\stackrel{\circ}{n o v} .2010$.

BARROS, João Álvaro Quintiliano. Abuso do direito. Jus Navigandi, Teresina, v.10, n. 727, p. 3, 2 jul. 2005. Disponível em: <http://jus.uol.com.br/revista/texto/6944>. Acesso em: 24 nov. 2010.

BOUlOS, Daniel M. Abuso de direito no Novo Código Civil. São Paulo: Método, 2006.

BRANDÃO, Débora Vanessa C.; GODOY, Leandro de Souza. Direito de Vizinhança. In: HIRONAKA, Giselda M. F. Novaes (Org.). Direito Civil. Vol. 4: Direito das Coisas. São Paulo: Revista dos Tribunais, 2008.

BRASIL. Lei n. ${ }^{\circ} 10.406$, de 10 de janeiro de 2002. Institui o Código Civil. Diário Oficial da União, Brasília, 11 jan. 2002. Disponível em: <http://www.planalto.gov.br/ccivil/leis /2002/ L10406.htm>. Acesso em: 1. $\frac{\mathrm{o}}{n}$ nov. 2010.

CARVALHO NETO, Inácio de. Abuso do direito. Curitiba: Juruá, 2009.

CAVAlIERI FILHO, Sergio. Programa de Responsabilidade Civil. São Paulo: Atlas, 2007.

COSTA, Judith Martins. Os avatares do abuso do direito e o rumo indicado pela boa-fé. BDJur, 2006, pp. 57-95. Trabalho apresentado no Congresso Internacional de Direito CivilConstitucional da Cidade do Rio de Janeiro (Rio de Janeiro, 21-23 de setembro de 2006). Disponível em: <http://www.fd.ul.pt>. Acesso em: 1. ${ }^{\circ}$ set. 2010.

FARIAS, Cristiano Chaves de; ROSENVALD, Nelson. Direitos Reais. 6. ed. Rio de Janeiro: Lumen Juris, 2009.

GONÇALVES, Carlos Roberto. Direito Civil brasileiro. São Paulo: Saraiva, 2005. 
MODENESI, Pedro. A relação entre o abuso do direito e a boa-fé objetiva. Revista eletrônica Direitos Fundamentais e Democracia, v.7, n.7, p.10, jan./jun. 2010. Disponível em: <http://revista eletronicardfd.unibrasil.com.br >. Acesso em: 1.․ㅡ nov. 2010.

MORAES, Maria Celina Bordin de. O Princípio da Solidariedade. Revista Trimestral de Direito Civil. Volume comemorativo do 60. ${ }^{\circ}$ Aniversário do Departamento de Direito da PUC-RJ, p. 10, 2000. Disponível em: 〈http://www.idcivil.com.br/pdf/ biblioteca9.pdf>. Acesso em: 1. ${ }^{\circ}$ nov. 2010.

PENTEADO, Luciano de Camargo. Direito das Coisas. São Paulo: Revista dos Tribunais, 2008.

RIO GRANDE DO SUL. Tribunal de Justiça. Décima Sétima Câmara Cível. Apelação Cível n. ${ }^{\circ}$ 70032330516. Relatora: Des. Liége Puricelli Pires. Porto Alegre, 25 de março de 2010. Disponível em: <http://www.tjrs.jus.br>. Acesso em: 7 fev. 2012.

. Décima Oitava Câmara Cível. Apelação Cível n. ${ }^{\circ}$ 70041865668. Relator: Des. Pedro Celso Dal Prá. Porto Alegre, 30 de junho de 2011. Disponível em: <http://www.tjrs.jus.br>. Acesso em: 7 fev. 2012.

. Vigésima Câmara Cível. Apelação Cível n. ${ }^{\circ} 70032510935$. Relator: Des. Glênio José Warsserstein Hekman. Porto Alegre, 30 de março de 2011. Disponível em: <http://www.tjrs.jus.br>. Acesso em: 7 fev. 2012.

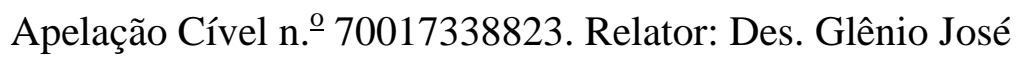
Warsserstein Hekman. Porto Alegre, 30 de março de 2011. Disponível em: <http://www.tjrs.jus.br>. Acesso em: 24 out. 2007.

RIZZARDO, Arnaldo. Direito das Coisas. Rio de Janeiro: Forense, 2007.

TEPEDINO, Gustavo; FACHIN, Luiz Edson. Diálogos sobre Direito Civil. Rio de Janeiro: Renovar, 2008.

; SCHREIBER, Anderson. A garantia da propriedade no Direito brasileiro. Revista da Faculdade de Direito de Campos, Campos dos Goytacazes, v. 6, n. 6, pp. 101-119, jun. 2005. Disponível em: <http://bdjur.stj.jus.br>. Acesso em: 1. ${ }^{o}$ set. 2010.

VENOSA, Silvio de Salvo. Direito Civil: direitos reais. 10. ed. São Paulo: Atlas, 2010.

\footnotetext{
${ }^{1}$ BRANDÃO, Débora Vanessa C.; GODOY, Leandro de Souza. Direito de Vizinhança. In: HIRONAKA, Giselda M. F. Novaes (Org.). Direito Civil. Vol.4: Direito das Coisas. São Paulo: Revista dos Tribunais, 2008, p. 116.

${ }^{2}$ MORAES, Maria Celina Bordin de. O Princípio da Solidariedade. Revista Trimestral de Direito Civil, volume comemorativo do 60. ${ }^{\circ}$ Aniversário do Departamento de Direito da PUC-RJ, Rio de Janeiro, p. 10, 2000. Disponível em: <http://www.idcivil.com.br/pdf/biblioteca9.pdf>. Acesso em: 1. o nov. 2010.

${ }^{3}$ FARIAS, Cristiano Chaves de; ROSENVALD, Nelson. Direitos Reais. 6. ed. Rio de Janeiro: Lumen Juris, 2009, p. 435.

${ }^{4}$ ADOLFO, Luiz Gonzaga Silva; OLIVEIRA, Paula Cristina Koerig de. Pra não dizer que não falamos de espinhos: a constitucionalização do Direito Civil e a difícil concretização da ideia de repersonalização em ações de direitos reais nos Tribunais brasileiros. Revista do Direito UNISC, Santa Cruz do Sul, n. 32, p. 57, jul./dez.
} 
2009.. Disponível em: <http://online.unisc.br/seer/index.php/direito/article/view/1187/887>. Acesso em: 1. ${ }^{\circ}$ nov. 2010.

${ }^{5}$ ARONNE, Ricardo. Propriedade intelectual e direitos reais: um primeiro retomar da obviedade. Revista do

Direito da UNISC, Santa Cruz do Sul, n.28, p. 218, jul./dez. 2007.

${ }^{6}$ FARIAS; ROSENVALD, 2009, op. cit., p. 440.

${ }^{7}$ RIZZARDO, Arnaldo. Direito das Coisas. Rio de Janeiro: Forense, 2007, p. 484.

${ }^{8}$ VENOSA, Silvio de Salvo. Direito Civil: direitos reais. 10. ed. São Paulo: Atlas, 2010, p. 291.

${ }^{9}$ PENTEADO, Luciano de Camargo. Direito das Coisas. São Paulo: Revista dos Tribunais, 2008, p. 250.

${ }^{10}$ FARIAS; ROSENVALD, 2009, op. cit., p. 451.

${ }^{11}$ FARIAS; ROSENVALD, 2009, op. cit., p. 452.

${ }^{12}$ FARIAS; ROSENVALD, 2009, op. cit., p. 452.

${ }^{13}$ Ibid., p. 455.

${ }^{14}$ FARIAS; ROSENVALD, 2009, op. cit., p. 456.

${ }^{15}$ Ibid., p. 460.

${ }^{16}$ FARIAS; ROSENVALD, 2009, op. cit., p. 464.

${ }^{17}$ Ibid., p. 467.

${ }^{18}$ FARIAS; ROSENVALD, 2009, op. cit., p. 466.

${ }^{19}$ PORCHEROT apud CARVALHO NETO, Inácio de. Abuso do direito. Curitiba: Juruá, 2009, p. 21.

${ }^{20}$ MODENESI, Pedro. A relação entre o abuso do direito e a boa-fé objetiva. Revista eletrônica Direitos

Fundamentais e Democracia, v.7, n.7, p. 10, jan./jun. 2010. Disponível em: <http://revista

eletronicardfd.unibrasil.com.br>. Acesso em: 1. ${ }^{\circ}$ nov. 2010.

${ }^{21}$ TRABUCHI, Alberto apud CARVALHO NETO, 2009, op. cit., p. 22.

${ }^{22}$ BARROS, João Álvaro Quintiliano. Abuso do direito. Jus Navigandi, Teresina, v.10, n. 727, p. 3, 2 jul. 2005.

Disponível em: 〈http://jus.uol.com.br/revista/texto/6944〉. Acesso em: 24 nov. 2010.

${ }^{23}$ BOULOS, Daniel M. Abuso de direito no Novo Código Civil. São Paulo: Método, 2006, p. 39.

${ }^{24}$ CARVALHO NETO, 2009, op. cit., p. 29.

${ }^{25}$ BOULOS, 2006, op. cit., p. 41.

${ }^{26} \mathrm{Ibid}, \mathrm{p} .42$.

${ }^{27}$ CAVALIERI FILHO, Sérgio. Programa de Responsabilidade Civil. São Paulo: Atlas, 2007, p. 142.

${ }^{28}$ RIO GRANDE DO SUL. Tribunal de Justiça. Décima Sétima Câmara Cível. Apelação Cível n. ${ }^{\circ}$ 70032330516. Relatora: Des. Liége Puricelli Pires. Porto Alegre, 25 de março de 2010. Disponível em: <http://www.tjrs.jus.br>. Acesso em: 7 fev. 2012.

${ }^{29}$ ASCENSÃO, José de Oliveira. A desconstrução do abuso de direito. In: AGUIAR JR., Ruy Rosado de (Org.). Jornada de Direito, 3. Anais. Brasília: Conselho da Justiça Federal, 2005, p. 32. Disponível em: $\left\langle\right.$ http://daleth.cjf.jus.br/revista/enunciados/IIIJornada.pdf >. Acesso em: 1. ${ }^{\circ}$ nov. 2010.

${ }^{30}$ ASCENSÃO, 2005, op. cit., p. 32.

${ }^{31}$ Ibid.

${ }^{32}$ BOULOS, 2006, op. cit., p. 42.

${ }^{33}$ BRASIL. Lei n.. $10.406 / 2002$. Código Civil. Disponível em: <http://www.planalto.gov.br/ccivil/leis/ 2002/ L10406.htm>. Acesso em: 1. ${ }^{\circ}$ nov. 2010. Art. 1.228.

${ }^{34}$ GONÇALVES, Carlos Roberto. Direito Civil brasileiro. São Paulo: Saraiva, 2005, p. 121.

${ }^{35}$ RIO GRANDE DO SUL. Tribunal de Justiça. Décima Oitava Câmara Cível. Apelação Cível n.o 70041865668. Relator: Des. Pedro Celso Dal Prá. Porto Alegre, 30 de junho de 2011. Disponível em: <http://www.tjrs.jus.br>. Acesso em: 7 fev. 2012.

${ }^{36}$ FARIAS; ROSENVALD, 2009, op. cit., p. 440.

${ }^{37}$ FARIAS; ROSENVALD, 2009, op. cit., p. 443.

${ }^{38}$ VENOSA, 2010, op. cit., p. 291.

${ }^{39}$ GONÇALVES, 2005, op. cit., p. 123.

${ }^{40}$ FARIAS; ROSENVALD, 3009, op. cit., p. 443.

${ }^{41}$ RIO GRANDE DO SUL. Tribunal de Justiça. Vigésima Câmara Cível. Apelação Cível n. .70032510935.

Relator: Des. Glênio José Warsserstein Hekman. Porto Alegre, 30 de março de 2011. Disponível em: <http://www.tjrs.jus.br>. Acesso em: 7 fev. 2012. 
${ }^{42}$ RIO GRANDE DO SUL. Tribunal de Justiça. Vigésima Câmara Cível. Apelação Cível n.․ำ 70017338823. Relator: Des. Glênio José Warsserstein Hekman. Porto Alegre, 30 de março de 2011. Disponível em: <http://www.tjrs.jus.br>. Acesso em: 24 out. 2007. 